\title{
都市近郊における土地利用秩序形成の方策
}

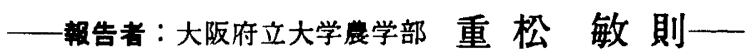

本研究は，都市近郊における晨地と晨外土地利 用との共存を意図したものであり，共存の計画モ デルを提示することによって，层地所有者や行政 に先行的な土地利用対策の重要性を認識させると ともに，今後の土地利用ならびに土地管理に対し て、これまでの過ちを綝り返さないための明快な 判断材料を与えるために行なわれた，以下，都市 近郊における土地利用転换の傾向, 土地利用秩序 形成の方策, 都市化段階と計画モデルについてそ の概要を述べる。

\section{I 土地利用転換の傾向}

都市近郊における土地利用転換の実態調査が, 戦前からの野菜産地である大阪市の東住吉区住道 地区で行なわれた。本地区の調査によると，本格 的な都市化は，市街化区域に指定された昭和44年 頃から始まり，当初住宅や商工業などの農外の土 地利用が目立ち始め，それらがみるみるうちに展 地を虫食していった。

このような都市化の進展にともない, 本地区の 野菜生産も, かつてのタイコン, ハクサイ, キャ ベッ等の重量野菜から，長期の鮮度保持の困嚾 な, 都市近郊野菜ともいうへき，ホウレンンウ， シュンキク，カイワレ等の野菜に変化し，策約的 な高収益尝業に転換してきている。なお本地区は 営展意欲が高いため，大阪府が昭和60年度に制定 した「都市緑宸区」の第 1 号に指定され，土地基 盤整储および生産施設整借等の助成事莱が行なわ れている。

昭和63年 1 月現在の本地区の農地占有事は51.7 \%であり，多くの展地か残っている。しかし，現 地に入ってみると，無秩序に混在する住宅や事業 所，倉庫等の建物が視界をさえぎり，農地が分断
されて一定の広がりをもって見えないため，予想 以上に都市化が進み，もはや農業はくずれ，生産 機能が失われているのではないかと思われる状況 である。

一方，本地区の住宅は，その大部分がミ二開発 によって建設され，1 戸当たりの数地は極めて狭 小である。このような状況が続くと, 今後, 本地 区は展地の緑機能は失われ，貣しい都市摆境に移 行していくものと思われる。

\section{II 土地利用秩序形成の方策}

\section{1 形成モデルの設定基华}

上述のような繁秩序な土地利用に対して, 土地 利用秩序をどう形成するかが大きな課題である。 そこで, 都市化の進行度の異なる事例に対して, (1)どの時点ではどの程度まで，より良好な土地利 用秩序が形成しうるのか，(2)あるいはどのように 土地利用の性格を転换しなければならないかを住 吉地区の昭和44年, 54年, 63年の各段陼の土地利 用実態から考察し，各時点での理想的なモデルを 設定する。土地利用計画モデル策定の基箁は次の ように要約することができる。

(1)都市緑贯区にふさわしい生活嫄境と良好な晨 業生産環境の而立。

(2)田園景钼の眺望を確保するため，土地利用の まとまりを図り，また都市的累観要素の見え方を 弱める一方, 暗確な樹林带 (10m幅) の即置等に よって，自然的景钼要素を高めるようにする。

(3)都市的土地利用についても，住宅地と工場や 倉庫などの業務地との混在を避け，区分する。

(4)辰地と公園及ひ榯林带を有機的，系統的に配 圈するとともに，教育環境の保全についても充分 配感する。 

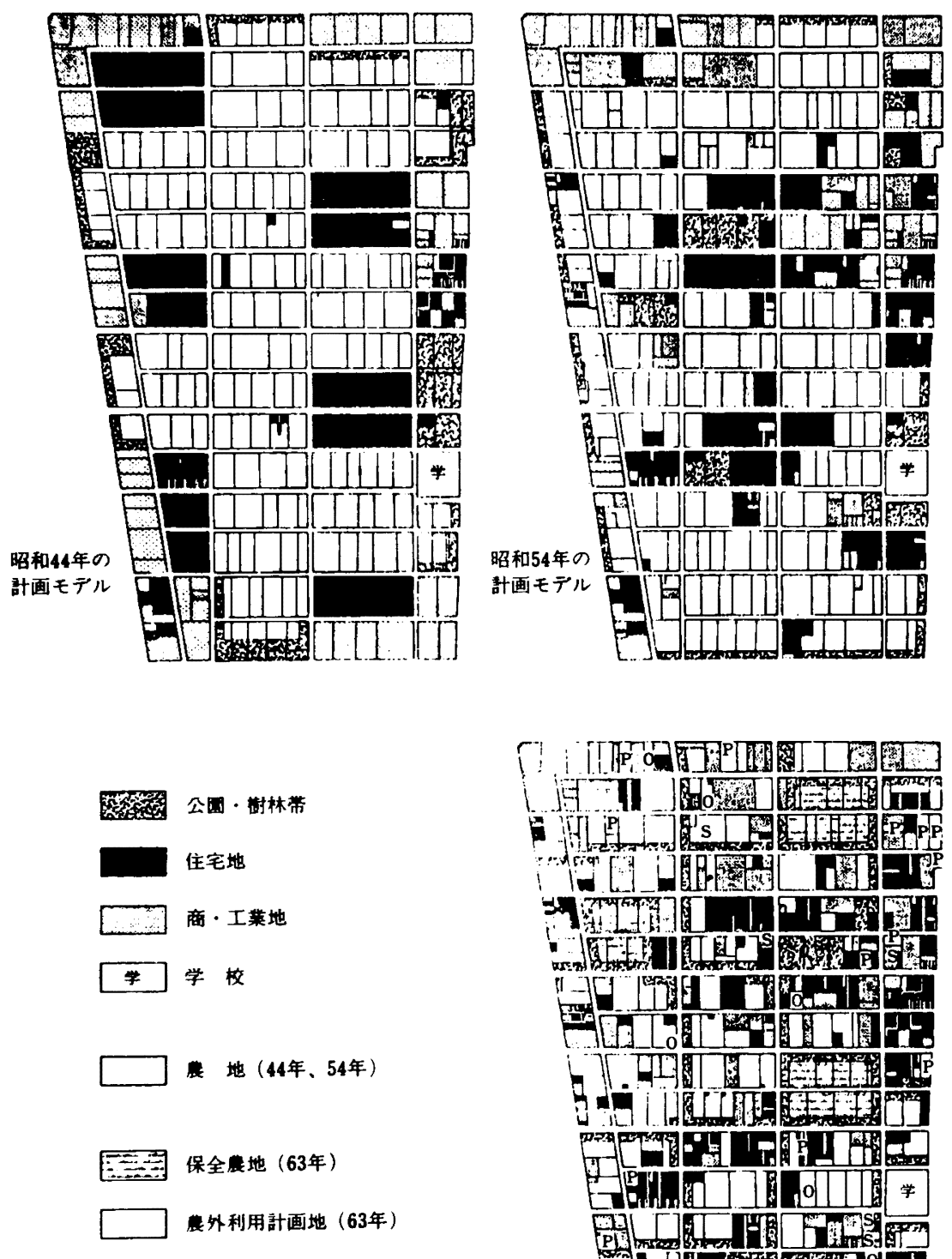
注：63年の叶面モデルでは、既存の

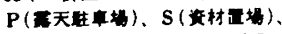
$\mathrm{O}$ (空地)は、当面そのまま存柱
している。

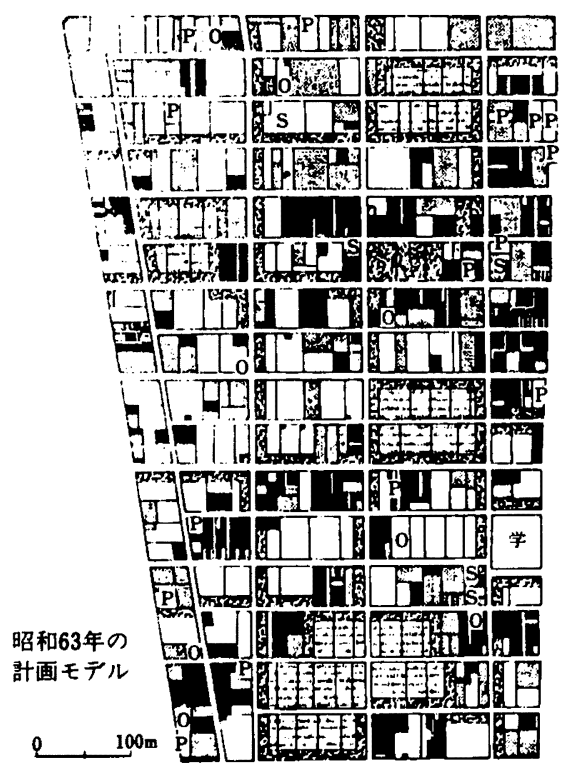

困近郊展地における都市化と対応する土地利用秩序形成のための計画モデル

䬤地、住宅地、商・工業地の面穔は、いすれも昭和63年に準じ。 
(5)既存の土地利用と建築物は, 原則として現状 のままとし，(1)（4)の命题達成の上で，移転が望 ましいものも，将来の老朽化に伴う建て替え時ま で存䈯する。但し简易施設については移転を前提 として計画する。

(6)露天駐車場およびガレージ，空地が存する面 積は，公園・緑地用地に充当できるしのとし，こ れに代わる駐車場用地は，公園・緑地の地下を利 用する。

(7)通過交通の遮断し，功公園・緑地のまとま りを図るために，道路教の一部は改廃できるもの とする。

以上の基汻に基づき策定した計画モデルは図に 示すとおりである。

\section{2 都市化段陼と計画モデル}

(1)昭和44年段陼の計画モデル

この段階では，農外の土地利用はわずかで，地
区面稓の $93 \%$ を占める䈨地は殆んと分断されるこ となく，良好な農業生産理境ならびに田園繁観を 保持している。

(2)昭和54年段階の対応モデル

この段階では無秩序な晨外土地利用が影著とな り，農地の分断などの影響が無視できない状況に なっている。しかし，一定の展地のまとまりと景 観的広がりはかろうじて残されている。

(3)昭和63年段階の対応モデル

この段階では都市化がさらに無秩序に進行して しまい，混在する住宅や事業所，倉庫によって視 界がさえぎられ，展地が分断されてしまっている ために，都市緑宸区にふさわしい土地利用秩序を 回復することは，もはや困難であると考えられ る。したがって，宸地所有者が展業の継続を希望 する場合には晨地の他用途への転用を凍結すると か, 脱展の場合には，土地の切り売りはつつしま なくてはならない。 